\title{
Quality characteristics of sourdough bread added with lactic acid bacteria culture solution and cinnamon extract
}

\author{
Chang Ki Huh ${ }^{1}$, Ki Hoon Shim ${ }^{2 *}$ \\ ${ }^{1}$ Department of Food Science Technology, Sunchon National University, Suncheon 57922, Korea \\ ${ }^{2}$ Department of Food and Cooking Science, Sunchon National University, Suncheon 57922, Korea
}

\section{유산균 배양액과 계피추출물을 첨가한 sourdough bread의 품질 특성}

\author{
허창기 ${ }^{1} \cdot$ 심기훈 $^{2 *}$ \\ ${ }^{1}$ 순천대학교 생명산업과학대학 식품공학과, ${ }^{2}$ 순천대학교 생명산업과학대학 조리과학과
}

\begin{abstract}
This study investigated quality characteristics of sourdough bread added with different amounts of lactic acid bacteria culture solution (LCBC) and cinnamon extract (Control: water $700 \mathrm{~mL}$, sample A: water $670 \mathrm{~mL}+\mathrm{LCBC} 30 \mathrm{~mL}$, sample B: water $670 \mathrm{~mL}+\mathrm{LCBC} 22.5 \mathrm{~mL}+$ Cinnamon extract $7.5 \mathrm{~mL}$, sample C: water $670 \mathrm{~mL}+\mathrm{LCBC} 15 \mathrm{~mL}+$ Cinnamon extract $15 \mathrm{~mL}$, sample D: water $670 \mathrm{~mL}+\mathrm{LCBC} 7.5 \mathrm{~mL}+$ Cinnamon extract $22.5 \mathrm{~mL}$ and sample E: water 670 $\mathrm{mL}+$ Cinnamon extract $30 \mathrm{~mL}$ ). The weight of dough was not significant between samples, and the weight of bread was highest in samples $D$. The volume and specific volume were the highest in sample $C$ but the baking loss rate was highest in the control $(\mathbf{p}<\mathbf{0 . 0 5})$. The $L$ value, springiness and cohesiveness were decreased as addition of cinnamon extract increased. However, a value, $b$ value, hardness, gumminess and chewiness were reversed. The sourdough bread produced by adding lactic acid bacteria culture solution improved the volume and texture. It was thought that it is helpful to add lactic acid bacteria culture solution and cinnamon extract for manufacturing a loaf of bread.
\end{abstract}

Key words : lactic acid bacteria cultured, cinnamon extract, sourdough, bread

\section{서 론}

현재 우리나라는 다양한 식문화가 유입되면서 쌀을 주식 으로 이용하지 않는 문화가 확산되고, 식생활 패턴이 변화 되면서 빵을 섭취하는 비율이 증가하고 있으며(1) 외식 증 가, 식품 산업 발전, 생활수준 향상 및 변화 등의 다양한 이유로 베이커리 관련 시장도 꾸준히 증가하고 있다(2). 과거에는 간식으로만 생각되었던 베이커리 제품들이 식사 대용으로 늘어나면서 소비자들도 인식의 변화가 생겨 영양 적으로 우수하고 건강에 도움이 되는 제품을 선호하면서

*Corresponding author. E-mail : khshim@sunchon.ac.kr Phone : 82-61-750-3697, Fax : 82-61-750-3690

Received 15 September 2017; Revised 18 October 2017; Accepted 19 October 2017.

Copyright (c) The Korean Society of Food Preservation. All rights reserved.
천연재료를 이용한 빵에 대한 관심이 높아지고 있다(3-6). 제빵과정에서 발효제를 이용하는 것은 가장 오래된 식품 발효 프로세스 중 하나로 sourdough는 반죽의 레올로지 특 성에 영향을 줘서 빵의 부피, 맛, 질감, 굳기 및 관능적 특성 에 영향을 주며, sourdough를 이용한 빵의 영양적 특성과 저장은 미생물의 생물학적 이용도와 전분의 노화를 지연을 개선하는 효과가 있다(7-10). Sourdough를 이용한 제빵 공 정은 빵의 향미를 개선시키는 것으로 알려져 있는데, 이는 일반 제빵과정보다 발효과정이 길어 휘발성 물질 및 방항족 화합물이 다량으로 생성되기 때문이다(11). 장시간에 걸친 발효는 빵을 굽는 동안 maillard 반응의 기질을 형성할 수 있는 많은 양의 아미노산을 확보할 수 있고, 반죽의 산도를 증가시켜 준다 $(12,13)$. 또한 식품 변질에 영향을 주는 미생 물을 억제하는 효과가 있어 sourdough를 이용한 제빵은 전 통적 가치, 미식적 품질 및 건강을 챙길 수 있는 방법 중 하나로 평가받고 있다(14,15). Sourdough로 제조한 빵은 19 
세기 전까지 이용한 전통적인 방법이었으나 제빵용 효모 개발과 제빵 제품의 안정성 등 기술적인 이유로 인하여 sourdough를 이용한 제빵 제조가 감소되었으나 소비자들의 건강에 대한 관심이 높아지면서 다시금 sourdough를 활용 한 제빵 제조가 증가하고 있다(16).

계피(Cinnamomi cassia cortex)는 알려져 있는 향미료 중 에서 가장 오래된 중의 하나로 특유의 향기가 있고 감미롭 고 온화한 맛을 가지고 있는 것이 특징으로 우리나라에서는 한약 재료로 많이 이용해왔고, 수정과, 떡, 과자 등에 첨가하 는 식재료로도 널리 이용하고 있다(17). 계피의 정유 성분 중에서 방향족 화합물인 cinnamic aldehyde는 항산화와 항 균에 효과가 있고 정유성분의 $80 \%$ 정도를 차지하며, 근래 에는 음료, 껌, 치약 및 화장품의 제조에 널리 이용되고 있으나(18-20) 따라서 본 연구는 천연 물질을 이용하여 제 조하는 제빵 관련 제품을 선호하는 소비자들의 요구와 lactic acid bacteria를 분리 동정하여 빵의 품질을 개선할 수 있는 젖산 발효법을 활용하여 유산균 배양액을 이용한 sourdough에 식빵의 향미 개선, 기능성 향상 등의 목적으로 계피를 추출물 형태로 첨가하여 식빵을 제조한 후 수분함 량, 색도, $\mathrm{pH}$, 산도 및 물성을 분석하였다. 이를 통하여 분리 동정한 유산균 배양액의 제빵 품질 개선 효과와 계피의 다양한 식품 첨가물로서의 가능성 등을 살펴보았다.

\section{재료 및 방법}

재 료

본 실험에서 사용한 유산균 배양액은 MRS 액체배지 (Lactobacilli MRS broth, Difco, Franklin Lakes, NJ, USA)에 $\mathrm{ALH}$ (Lactobacillus sakei subsp. ALI033)를 2\% (v/v) 접종하 여 48 시간 동안 $37^{\circ} \mathrm{C}$ 에서 배양한 후 $4^{\circ} \mathrm{C}$ 에서 10 분간 3,000 $\mathrm{rpm}$ 으로 원심분리하여 사용하였다. 계피 주정 추출물은 발효주정 $100 \mathrm{~mL}$ 에 대하여 계피가루(제천한방약초, 베트 남) $10 \mathrm{~g}$ 을 첨가하여 상온에서 24 시간 추출 후 $4^{\circ} \mathrm{C}$ 에서 10 분간 $10,000 \mathrm{rpm}$ 으로 원심분리하여 사용하였고, 식빵 제 조에는 계피주정추출물을 사용하였다. 식빵 재료로 사용한 강력분 밀가루(Daehan flour mills, Co., Seoul, Korea), 쇼트 닝(Hains Co., Seoul, Korea), 이스트(Jenico Foods Co., Seoul, Korea), 설탕(Samyang Co., Seoul, Korea), 소금(Dongwon Co., Seoul, Korea) 및 탈지분유(Seoul Milk Co., Seoul, Korea)는 시중에서 구입하여 사용하였다.

\section{유산균 배양액과 계피추출물을 첨가한 식빵 제조}

유산균 배양액과 계피추출물을 첨가한 식빵은 직접반죽 법으로 Table 1 과 같이 제조하였다. 강력분은 전체 중량의 $56.24 \%$, 물은 $32.80 \%$ 를 기본으로 하였고 유산균 배양약과 계피 추출물은 전체 중량의 $2.5 \%$ 로 물을 대신하여 첨가하
였다. 유산균 배양액과 계피추출물을 첨가하지 않고 제조 한 식빵을 대조구로 하였고, A 시료는 유산균 배양액만 $30 \mathrm{~g}, \mathrm{~B}$ 시료는 유산균 배양액 $22.5 \mathrm{~g}$ 과 계피추출물 7.5 $\mathrm{g}, \mathrm{C}$ 시료는 유산균 배양액 $15 \mathrm{~g}$ 과 계피추출물 $15 \mathrm{~g}, \mathrm{D}$ 시료는 유산균 배양액 $7.5 \mathrm{~g}$ 과 계피추출물 $22.5 \mathrm{~g}$ 그리고 $\mathrm{E}$ 시료는 계피추출물만 $30 \mathrm{~g}$ 첨가하였다. 이외에 쇼트닝 $1.68 \%$, 설탕 $3.38 \%$, 소금 $0.84 \%$, 탈지분유 $2.25 \%$, 생 이스트 $2.81 \%$ 를 첨가하여 사용하였다. 반죽은 저속에서 2 분 동안 수화 후 쇼트닝을 첨가하여 중속 5 분, 고속 5 분으로 하였다. 1 차 발효는 습도 $75 \%$, 온도 $27^{\circ} \mathrm{C}$ 에서 40 분간 1 차 발효를 한 후 $180 \mathrm{~g}$ 씩 분할하여 15 분 동안 중간 발효를 하였다. 2 차 발효는 온도 $38^{\circ} \mathrm{C}$, 습도 $85 \%$ 에서 시행하였고, 윗불 $200^{\circ} \mathrm{C}$, 아랫불 $180^{\circ} \mathrm{C}$ 오븐에서 30 분간 구웠다.

Table 1. Formula of bread loaf added with lactic acid bacteria culture solution and cinnamon extract

\begin{tabular}{ccccccc}
\hline Samples $^{1)}$ & Control & A & B & C & D & E \\
\hline Wheat flour & 56.24 & 56.24 & 56.24 & 56.24 & 56.24 & 56.24 \\
Shortening & 1.68 & 1.68 & 1.68 & 1.68 & 1.68 & 1.68 \\
Sugar & 3.38 & 3.38 & 3.38 & 3.38 & 3.38 & 3.38 \\
Salt & 0.84 & 0.84 & 0.84 & 0.84 & 0.84 & 0.84 \\
Defatted milk powder & 2.25 & 2.25 & 2.25 & 2.25 & 2.25 & 2.25 \\
Yeast & 2.81 & 2.81 & 2.81 & 2.81 & 2.81 & 2.81 \\
Water & 32.80 & 31.40 & 31.40 & 31.40 & 31.40 & 31.40 \\
Lactic acid bacteria cultured & 0 & 1.40 & 1.05 & 0.70 & 0.35 & 0 \\
Cinnamon extract & 0 & 0 & 0.35 & 0.70 & 1.05 & 1.40 \\
\hline
\end{tabular}

${ }^{1)}$ Control, water $700 \mathrm{~g}$; A sample, water $670 \mathrm{~g}+$ Lactic acid bacteria cultured $30 \mathrm{~g}$; B sample, water $670 \mathrm{~g}+$ Lactic acid bacteria cultured $22.5 \mathrm{~g}+$ Cinnamon extract 7.5 $\mathrm{g}$; C sample, water $670 \mathrm{~g}+$ Lactic acid bacteria cultured $15 \mathrm{~g}+$ Cinnamon extract $15 \mathrm{~g}$; D sample, water $670 \mathrm{~g}+$ Lactic acid bacteria cultured $7.5 \mathrm{~g}+$ Cinnamon extract $22.5 \mathrm{~g}$; E sample, water $670 \mathrm{~g}+$ Cinnamon extract $30 \mathrm{~mL}$.

\section{식빵의 무게, 부피, 비용적 및 굽기손실율 측정}

유산균 배양액과 계피추출물을 첨가한 식빵의 무게는 실온에서 방냉한 후 측정하였고, 부피는 종자치환법(21)으 로 3회 반복하여 측정한 후 평균값을 나타내었다. 빵의 비용 적은 부피를 무게로 나눠서 계산하였다. 굽기손실율은 다 음의 식으로 계산하였다.

$$
\text { 굽기손실 율 }(\%)=\frac{\text { 반죽중량 }(\mathrm{g})-\text { 식빵중량 }(\mathrm{g})}{\text { 반죽중량 }(\mathrm{g})} \times 100
$$

\section{식빵의 수분함량 측정}

유산균 배양액과 계피추출물을 첨가한 식빵의 수분함량 은 상압가열건조법(22)으로 측정하였다. 


\section{식빵의 $\mathrm{pH}$ 측정}

유산균 배양액과 계피추출물을 첨가한 식빵의 $\mathrm{pH}$ 는 시 료에 증류수를 10배 넣고 교반한 다음 $\mathrm{pH}$ meter(Accument 925 pH/ion meter, Fisher Scientific, Hampton, NH, USA)를 이용하여 측정하였다.

\section{식빵의 적정산도 측정}

유산균 배양액과 계피추출물을 첨가한 식빵의 적정산도 는 시료에 증류수를 10 배 넣고 실온에서 30 분간 교반 후 $3,000 \mathrm{rpm}$ 에서 30 분간 원심분리(MF 600, Hanil Science Industrial, Kimpo, Korea)하여 상등액을 $0.1 \mathrm{~N} \mathrm{NaOH}$ 로 중화 적정하였다. 산도는 소요된 $\mathrm{NaOH}$ 의 양으로 다음 계산식에 따라 lactic $\operatorname{acid}(\mathrm{mg} \%)$ 로 표시하였다.

$$
\text { 적정산도 }(\mathrm{mg} \%)=\frac{\mathrm{V} \times \mathrm{F} \times \mathrm{D} \times 0.009}{\mathrm{~S}} \times 100
$$

$\mathrm{V}: 0.01 \mathrm{~N} \mathrm{NaOH}$ 용액의 적정소비량 $(\mathrm{mL})$

$\mathrm{F}$ : $0.01 \mathrm{~N} \mathrm{NaOH}$ 용액의 역가

$\mathrm{D}$ : 희석배수

0.009 : Lactic acid 계수 값

$\mathrm{S}:$ 시료채취량

\section{식빵의 색도 측정}

유산균 배양액과 계피추출물을 첨가한 식빵의 색도는 색차계(JC 801S, Tokyo, Japan)를 사용하여 L(백색도), a(적 색도), $\mathrm{b}$ (황색도) 값을 측정하였다.

\section{식빵의 물성 측정}

유산균 배양액과 계피추출물을 첨가한 식빵의 물성은 식빵의 중심을 $2 \times 2 \times 1 \mathrm{~cm}$ 로 절단하여 texture analyzer (TA-XT2i, Stable Micro System Co., Surrey, UK)를 이용하 여 texture profile analysis로 측정하였다. Compression force 의 측정조건은 test type: measure force compression, test speed: $0.1 \mathrm{~mm} / \mathrm{sec}$, strain: $50 \%$, probe: $\mathrm{P} / 45$ 으로 하였다. 위의 측정 후 얻어진 force-distance curve로부터 경도, 탄력 성, 응집성, 점착성 및 씹힘성의 측정하였다.

\section{통계처리 방법}

실험결과는 SPSS 프로그램을 이용하여 일원배치 분산분 석(ANOVA) 하였으며, $\mathrm{p}<0.05$ 수준에서 Duncan's multiple range test로 시료간의 차이를 검증을 실시하였다.

\section{결과 및 고찰}

\section{식빵의 무게, 부피, 비용적 및 굽기 손실율}

유산균 배양액과 계피추출물을 물 대신에 첨가하여 제조 한 식빵의 무게, 부피, 비용적 및 굽기 손실율 측정한 결과는 Table 2와 같다. 식빵 반죽의 무게는 541.35-543.03 g으로 $\mathrm{B}$ 시료 식빵 반죽이 가장 무거웠고, $\mathrm{C}$ 시료 식빵 반죽이 가장 가벼운 것으로 나타났으나 각각의 식빵 반죽 무게 차이는 없었다. 식빵의 무게는 465.41-494.24 g으로 계피추 출물만 첨가한 $\mathrm{E}$ 식빵이 가장 무거웠고, 대조구가 가장 가벼웠으며 각각의 식빵 무게를 평균 비교하였을 때 통계적 으로 유의미한 차이가 있는 것으로 나타났다. 계피추출물 첨가량이 감소하고, 유산균 배양액이 증가할수록 식빵의 무게는 감소하는 것으로 나타났다. 식빵의 부피는 $\mathrm{C}$ 식빵이 $1,653.63 \mathrm{~mL}$ 로 가장 높았고, 유산균 배양액을 첨가하지 않 고 계피추출물만을 첨가한 $\mathrm{E}$ 식빵이 $1,065.30 \mathrm{~mL}$ 로 가장 낮았으며, 각각의 식빵 부피는 통계적으로 유의미한 차이 가 있는 것으로 나타났다. 빵 제조시 부피가 작으면 관능적 으로 선호도가 감소하지만, 동일한 무게인 경우에는 부피 가 크면 부드러운 빵이 되어 관능적 선호도가 높아지는 것으로 알려져 있어(23) $\mathrm{C}$ 식빵의 경우 부피와 관능적 요인 이 개선된 것을 알 수 있었다. 식빵의 비용적은 부피와 마찬 가지로 C 식빵이 $3.46 \mathrm{~mL} / \mathrm{g}$ 으로 가장 높았고, 유산균 배양 액을 첨가하지 않고 계피추출물만 첨가하여 제조한 $\mathrm{E}$ 식빵

Table 2. Weight, volume, specific volume and baking loss rate of loaf bread with lactic acid bacteria cultured and cinnamon extract

\begin{tabular}{cccccc}
\hline Samples $^{1)}$ & $\begin{array}{c}\text { Weight of dough } \\
(\mathrm{g})\end{array}$ & $\begin{array}{c}\text { Weight of loaf bread } \\
(\mathrm{g})\end{array}$ & $\begin{array}{c}\text { Volume of loaf bread } \\
(\mathrm{mL})\end{array}$ & $\begin{array}{c}\text { Specific volume } \\
(\mathrm{mL} / \mathrm{g})\end{array}$ & $\begin{array}{c}\text { Baking loss } \\
\text { rate }(\%)\end{array}$ \\
\hline Control & $541.61 \pm 0.97$ & $465.41 \pm 1.45^{\mathrm{d} 2)}$ & $1,538.83 \pm 21.07^{\mathrm{c}}$ & $3.31 \pm 0.04^{\mathrm{b}}$ & $14.07 \pm 0.15^{\mathrm{a}}$ \\
A & $541.59 \pm 1.12$ & $466.45 \pm 2.71^{\mathrm{d}}$ & $1,554.00 \pm 6.53^{\mathrm{bc}}$ & $3.33 \pm 0.01^{\mathrm{b}}$ & $13.87 \pm 0.42^{\mathrm{a}}$ \\
B & $543.03 \pm 2.02$ & $472.14 \pm 3.58^{\mathrm{cd}}$ & $1,575.67 \pm 7.20^{\mathrm{b}}$ & $3.34 \pm 0.03^{\mathrm{b}}$ & $13.05 \pm 0.69^{\mathrm{ab}}$ \\
C & $541.35 \pm 0.63$ & $477.59 \pm 1.15^{\mathrm{c}}$ & $1,653.63 \pm 25.94^{\mathrm{a}}$ & $3.46 \pm 0.06^{\mathrm{a}}$ & $11.78 \pm 0.24^{\mathrm{bc}}$ \\
D & $542.52 \pm 1.05$ & $485.04 \pm 0.87^{\mathrm{b}}$ & $1,545.07 \pm 3.27^{\mathrm{c}}$ & $3.19 \pm 0.01^{\mathrm{c}}$ & $10.59 \pm 0.33^{\mathrm{c}}$ \\
E & $541.39 \pm 1.05$ & $494.24 \pm 8.81^{\mathrm{a}}$ & $1,065.30 \pm 11.92^{\mathrm{d}}$ & $2.16 \pm 0.04^{\mathrm{d}}$ & $8.71 \pm 1.76^{\mathrm{d}}$ \\
\hline
\end{tabular}

${ }^{1)}$ Control, water $700 \mathrm{~g}$; A sample, water $670 \mathrm{~g}+$ Lactic acid bacteria cultured $30 \mathrm{~g}$; B sample, water $670 \mathrm{~g}+$ Lactic acid bacteria cultured $22.5 \mathrm{~g}+\mathrm{Cinnamon}$ extract $7.5 \mathrm{~g}$; C sample, water $670 \mathrm{~g}+$ Lactic acid bacteria cultured $15 \mathrm{~g}+$ Cinnamon extract $15 \mathrm{~g}$; D sample, water $670 \mathrm{~g}+$ Lactic acid bacteria cultured $7.5 \mathrm{~g}+\mathrm{Cinnamon}$ extract $22.5 \mathrm{~g}$; E sample, water $670 \mathrm{~g}+$ Cinnamon extract $30 \mathrm{~mL}$.

${ }^{2)}$ All values are mean \pm SD. Mean \pm SD in column by different superscripts are significantly different at the $p<0.05$ by Duncan's multiple range test. 
이 $2.16 \mathrm{~mL} / \mathrm{g}$ 으로 가장 낮았으며, 각각의 식빵 비용적은 통계적으로 유의미한 차이가 있는 것으로 나타났다. 제빵 제품의 비용적은 첨가되는 부재료의 양과 종류, 단백질의 양과 질 그리고 글루텐 발달정도 등에 따라 영향을 받으며, 최종 제빵제품의 비용적이 높을수록 제빵 반죽의 발효과정 에서 air cell이 균일하게 잘 발달하여 탄력이 좋은 제빵 제품이 나온다고 하여(24) 부피와 마찬가지로 C 식빵이 좋은 제품으로 생각된다. 굽기 손실율은 굽는 과정에서 수 분과 휘발성 물질이 증발에 의해 영향을 받는 것으로 알려 져 있는데, 본 연구결과에서는 대조구에서 $14.07 \%$ 로 가장 높았고, 유산균 배양액을 첨가하지 않고 계피추출물만 첨 가하여 제조한 $\mathrm{E}$ 식빵이 $8.71 \%$ 로 가장 낮았으며, 각각의 굽기 손실율은 통계적으로 유의미한 차이가 있는 것으로 나타났다. 굽기 손실율은 굽는 과정에서 열에 의해 휘발성 물질인 알코올과 이산화탄소 또는 수분이 증발에 의해 영향 을 받는 것으로 알려져 있는데(25), 계피 추출물 첨가량이 증가할수록 굽기 손실율이 감소하는 것으로 나타났다.

\section{식빵의 수분함량, $\mathrm{pH}$ 및 적정산도}

유산균 배양액과 계피추출물을 물 대신에 첨가하여 제조 한 식빵의 수분함량, $\mathrm{pH}$ 및 적정산도를 측정한 결과는 Table 3 과 같다. 제조 당일 방냉하여 측정한 수분함량은 유산균 배양액만을 첨가하여 제조한 식빵이 $40.74 \%$ 로 가장 높았고, 유산균 배양액을 첨가하지 않고 계피추출물만을 첨가하여 제조한 식빵에서 $37.96 \%$ 로 가장 낮았으며, 각각 의 식빵 수분함량은 통계적으로 유의미한 차이가 있는 것으 로 나타났다. 유산균 배양액만을 첨가하여 제조한 식빵은 대조구보다 높은 수분함량을 보였으며, 계피추출물 첨가량 이 증가할수록 식빵의 수분함량은 감소하는 경향을 보였 다. 이와 같은 결과는 쌀 천연 발효액종을 첨가한 우리밀 식빵의 연구(26)와 발효미강 첨가량이 증가할수록 sourdough를 이용한 바게트 빵의 연구(27)에서도 쌀 발효액 종과 발효미강 첨가량이 증가할수록 수분함량이 낮아지는 경향과 유사하였다. 식빵의 $\mathrm{pH}$ 를 측정한 결과에서는 유산 균 배양액만을 첨가하여 제조한 식빵에서 6.58 로 가장 높았 으며, 유산균 배양액을 첨가하지 않고 계피추출물만을 첨 가하여 제조한 식빵에서 6.36으로 가장 낮았으며, 각각의 식빵 $\mathrm{pH}$ 는 통계적으로 유의미한 차이가 있는 것으로 나타 났다. 식빵의 적정산도를 측정한 결과는 $\mathrm{pH}$ 측정과 반대로 유산균 배양액을 첨가하지 않고 계피추출물만을 첨가하여 제조한 식빵에서 $8.55 \mathrm{mg} \%$ 로 가장 높았고, 유산균 배양액 만을 첨가하여 제조한 식빵에서 $7.66 \mathrm{mg} \%$ 로 가장 낮았으나 각각의 식빵 적정산도는 통계적으로 유의미한 차이가 없는 것으로 나타났다. 유산균 배양액 첨가량이 감소하고 계피 추출물 첨가량이 증가할수록 식빵의 산도는 증가하는 것으 로 나타났다. 무화과 액종을 이용한 sourdough bread의 연구 (16)에서 무화과 액종 첨가량이 증가할수록 적정산도는 높
아지고 $\mathrm{pH}$ 는 낮아지는 경향으로 본 연구와 유사하였다. 이와 같이 적정산도가 증가하는 결과는 sourdough를 제조 에 사용되는 stater 내 존재하는 미생물의 생균수가 증가와 초산 또는 젖산균과 같은 유기산이 생성되어 증가하는 것으 로 알려져 있다 $(16,28)$

Table 3. Moisture, pH and titrated acidity of bread loaf added with lactic acid bacteria culture solution and cinnamon extract

\begin{tabular}{cccc}
\hline Samples $^{1)}$ & Moisture $(\%)$ & $\mathrm{pH}$ & Titrated acidity $(\mathrm{mg} \%)$ \\
\hline Control & $40.15 \pm 0.28^{\mathrm{b} 2)}$ & $6.44 \pm 0.04^{\mathrm{c}}$ & $7.79 \pm 0.24$ \\
A & $40.74 \pm 0.23^{\mathrm{a}}$ & $6.58 \pm 0.01^{\mathrm{a}}$ & $7.66 \pm 0.16$ \\
B & $39.82 \pm 0.04^{\mathrm{b}}$ & $6.47 \pm 0.01^{\mathrm{c}}$ & $7.72 \pm 0.33$ \\
C & $39.79 \pm 0.16^{\mathrm{b}}$ & $6.52 \pm 0.01^{\mathrm{b}}$ & $8.15 \pm 0.60$ \\
D & $38.88 \pm 0.16^{\mathrm{c}}$ & $6.50 \pm 0.00^{\mathrm{b}}$ & $8.46 \pm 0.59$ \\
E & $37.96 \pm 0.60^{\mathrm{d}}$ & $6.36 \pm 0.02^{\mathrm{d}}$ & $8.55 \pm 0.38$ \\
\hline
\end{tabular}

${ }^{1)}$ Control, water $700 \mathrm{~g}$; A sample, water $670 \mathrm{~g}+$ Lactic acid bacteria cultured $30 \mathrm{~g}$; B sample, water $670 \mathrm{~g}+$ Lactic acid bacteria cultured $22.5 \mathrm{~g}+$ Cinnamon extract 7.5 $\mathrm{g}$; C sample, water $670 \mathrm{~g}+$ Lactic acid bacteria cultured $15 \mathrm{~g}+$ Cinnamon extract 15 $\mathrm{g}$; D sample, water $670 \mathrm{~g}+$ Lactic acid bacteria cultured $7.5 \mathrm{~g}+$ Cinnamon extract 22.5 g; E sample, water $670 \mathrm{~g}+$ Cinnamon extract $30 \mathrm{~mL}$.

${ }^{2)}$ All values are mean \pm SD. Mean \pm SD in column by different superscripts are significantly different at the $\mathrm{p}<0.05$ by Duncan's multiple range test.

\section{식빵의 색도}

유산균 배양액과 계피추출물을 물 대신에 첨가하여 제조 한 식빵의 색도를 측정한 결과는 Table 4 와 같다. 제과제빵 의 색은 동일한 조건에서는 당에 의해 영향을 받고, 비효소 적 갈변 반응과 카라멜화 반응 등에 의해 영향을 받는다 (29). 식빵의 백색도를 측정한 결과에서는 대조구에서 80.22로 가장 높았고, 유산균 배양액을 첨가하지 않고 계피 추출물만을 첨가하여 제조한 $\mathrm{E}$ 식빵에서 58.32로 가장 낮았 으며, 각각의 식빵 백색도는 통계적으로 유의미한 차이가 있는 것으로 나타났다. 식빵의 적색도를 측정한 결과에서 는 유산균 배양액을 첨가하지 않고 계피추출물만을 첨가하 여 제조한 E 식빵에서 6.39로 가장 높았고, 유산균 배양액만 을 첨가하여 제조한 $\mathrm{A}$ 식빵에서 -1.91로 가장 낮았으며, 각각의 식빵 적색도는 통계적으로 유의미한 차이가 있는 것으로 나타났다. 식빵의 황색도를 측정한 결과도 적색도 와 마찬가지로 유산균 배양액을 첨가하지 않고 계피추출물 만을 첨가하여 제조한 $\mathrm{E}$ 식빵에서 23.80으로 가장 높았고, 유산균 배양액만을 첨가하여 제조한 A 식빵에서 19.88로 가장 낮았으며, 각각의 식빵 황색도는 통계적으로 유의미 한 차이가 있는 것으로 나타났다. 유산균 배양액 첨가비율 이 감소하고 계피추출물 첨가비율이 증가할수록 백색도는 낮아지고, 적색도와 황색도는 증가하는 것으로 계피추출물 이 식빵의 색을 어둡게 만드는 것으로 나타났다. 계피 분말 을 첨가한 스펀지케이크 연구(30)와 계피 분말을 첨가한 쿠키의 연구(31)에서 계피 분말 첨가량이 증가할수록 백색 도와 적색도는 증가하여 본 연구 결과와 일치하였고, 황색 
도는 감소하여 다른 결과를 보였는데 이는 본 연구에서는 계피를 분말 형태가 아닌 추출물 형태로 첨가하였기 때문으 로 생각된다.

Table 4. Hunter's color value of bread loaf added with lactic acid bacteria culture solution and cinnamon extract

\begin{tabular}{cccc}
\hline Samples $^{1)}$ & $\mathrm{L}$ & $\mathrm{a}$ & $\mathrm{b}$ \\
\hline Control & $80.22 \pm 0.20^{\mathrm{a} 2)}$ & $-1.77 \pm 0.32^{\mathrm{e}}$ & $20.55 \pm 0.35^{\mathrm{b}}$ \\
A & $79.88 \pm 0.28^{\mathrm{a}}$ & $-1.91 \pm 0.70^{\mathrm{e}}$ & $19.88 \pm 0.19^{\mathrm{c}}$ \\
B & $72.99 \pm 0.32^{\mathrm{b}}$ & $2.04 \pm 0.23^{\mathrm{d}}$ & $19.79 \pm 0.44^{\mathrm{c}}$ \\
C & $68.89 \pm 0.38^{\mathrm{c}}$ & $2.91 \pm 0.81^{\mathrm{c}}$ & $20.53 \pm 0.25^{\mathrm{b}}$ \\
D & $65.04 \pm 0.41^{\mathrm{d}}$ & $3.98 \pm 0.67^{\mathrm{b}}$ & $20.85 \pm 0.18^{\mathrm{b}}$ \\
E & $58.32 \pm 0.70^{\mathrm{e}}$ & $6.39 \pm 0.25^{\mathrm{a}}$ & $23.80 \pm 0.03^{\mathrm{a}}$ \\
\hline
\end{tabular}

${ }^{1)}$ Control, water $700 \mathrm{~g}$; A sample, water $670 \mathrm{~g}+$ Lactic acid bacteria cultured $30 \mathrm{~g}$; B sample, water $670 \mathrm{~g}+$ Lactic acid bacteria cultured $22.5 \mathrm{~g}+$ Cinnamon extract 7.5 $\mathrm{g}$; C sample, water $670 \mathrm{~g}+$ Lactic acid bacteria cultured $15 \mathrm{~g}+$ Cinnamon extract $15 \mathrm{~g}$; D sample, water $670 \mathrm{~g}+$ Lactic acid bacteria cultured $7.5 \mathrm{~g}+$ Cinnamon extract $22.5 \mathrm{~g}$; E sample, water $670 \mathrm{~g}+$ Cinnamon extract $30 \mathrm{~mL}$.

${ }^{2)}$ All values are mean $\pm \mathrm{SD}$. Mean $\pm \mathrm{SD}$ in column by different superscripts are significantly different at the $p<0.05$ by Duncan's multiple range test.

\section{식빵의 물성}

유산균 배양액과 계피추출물을 물 대신에 첨가하여 제조 한 식빵의 물성을 측정한 결과는 Table 5 와 같다. 식빵의 경도를 측정한 결과에서는 유산균 배양액을 첨가하지 않고 계피추출물만을 첨가하여 제조한 $\mathrm{E}$ 식빵에서 $6.92 \mathrm{~kg}$ 으로 가장 높았고, 유산균 배양액만을 첨가하여 제조한 $\mathrm{A}$ 식빵에 서 $3.31 \mathrm{~kg}$ 으로 가장 낮았으며, 각각의 식빵 경도는 통계적 으로 유의미한 차이가 있는 것으로 나타났다. 유산균 배양 액 첨가비율이 감소하고 계피추출물 첨가비율이 증가할수 록 식빵의 경도는 증가하는 것으로 나타났고, 유산균 배양 액을 $0.70 \mathrm{~mL}$ 이상 첨가한 $\mathrm{A}, \mathrm{B}, \mathrm{C}$ 시료는 대조구보다 부드러운 것으로 나타났다. 식빵의 탄력성을 측정한 결과 에서는 계피추출물을 첨가하지 않고 유산균 배양액만을 첨가하여 제조한 $\mathrm{A}$ 식빵에서 0.91 로 가장 높았고, 계피추출 물만 첨가하여 제조한 $\mathrm{E}$ 식빵에서 0.82 로 가장 낮았으며, 각각의 식빵 탄력성은 통계적으로 유의미한 차이가 없는 것으로 나타났다. 계피추출물 첨가비율이 증가할수록 식빵 의 탄력성은 감소하는 것으로 나타났다. 식빵의 응집성을 측정한 결과에서는 대조구, $\mathrm{A}$ 및 $\mathrm{B}$ 식빵에서 0.52 로 가장 높게 나타났고, 계피추출물만을 첨가하여 제조한 $\mathrm{E}$ 식빵에 서 0.49 로 가장 낮았으나 각각의 식빵 응집성은 통계적으로 유의미한 차이가 없는 것으로 나타났다. 식빵의 점착성과 씹힘성을 측정한 결과에서는 계피추출물만을 첨가하여 제 조한 $\mathrm{E}$ 식빵에서 각각 3.38 과 2.78 로 가장 높았고, 계피추출 물을 첨가하지 않고 유산균 배양액만을 첨가하여 제조한 $\mathrm{A}$ 식빵에서 각각 1.71 과 1.55 로 가장 낮았으며, 각각의 식빵 점착성과 씹힘성은 통계적으로 유의미한 차이가 있는 것으 로 나타났다. 점착성과 씹힘성은 경도와 같이 유산균 배양
액 첨가비율이 감소하고 계피추출물 첨가비율이 증가할수 록 증가하는 것으로 나타났다. Jung 등(16)의 무화과 액종을 이용한 sourdough bread의 연구와 Hwang 등(27)의 발효미 강 sourdough를 이용한 바게트 빵의 연구에서도 경도, 점착 성 및 씹힘성은 증가하였고, 탄력성과 응집성은 감소하여 본 연구결과와 유사한 경향을 보였다. An과 Lee(23)의 연구 에서는 물성 측정 모든 항목이 사워종 분말 첨가량이 증가 할수록 높아지는 경향으로 본 연구와는 다소 상이한 결과를 보였는데 계피 추출물을 첨가하여 식빵을 제조한 본 연구와 는 달리 다른 부재료를 첨가하지 않았기 때문으로 생각된 다.

Table 5. Texture characteristics of bread loaf added with lactic acid bacteria culture solution and cinnamon extract

\begin{tabular}{cccccc}
\hline Samples $^{1}$ & Hardness (kg) & Springiness & Cohesiveness & Gumminess & Chewiness \\
\hline Control & $5.54 \pm 0.81^{\mathrm{b} 2}$ & $0.90 \pm 0.00^{\mathrm{b}}$ & $0.52 \pm 0.02$ & $2.92 \pm 0.48^{\mathrm{b}}$ & $2.62 \pm 0.43^{\mathrm{a}}$ \\
A & $3.31 \pm 0.28^{\mathrm{d}}$ & $0.91 \pm 0.01^{\mathrm{a}}$ & $0.52 \pm 0.01$ & $1.71 \pm 0.14^{\mathrm{d}}$ & $1.55 \pm 0.12^{\mathrm{c}}$ \\
B & $3.58 \pm 0.49^{\mathrm{d}}$ & $0.90 \pm 0.00^{\mathrm{b}}$ & $0.52 \pm 0.01$ & $1.86 \pm 0.25^{\mathrm{d}}$ & $1.67 \pm 0.22^{\mathrm{c}}$ \\
C & $4.55 \pm 0.53^{\mathrm{c}}$ & $0.90 \pm 0.01^{\mathrm{b}}$ & $0.51 \pm 0.05$ & $2.32 \pm 0.40^{\mathrm{c}}$ & $2.10 \pm 0.36^{\mathrm{b}}$ \\
D & $6.09 \pm 0.45^{\mathrm{b}}$ & $0.89 \pm 0.00^{\mathrm{c}}$ & $0.51 \pm 0.02$ & $3.09 \pm 0.29^{\mathrm{ab}}$ & $2.74 \pm 0.27^{\mathrm{a}}$ \\
E & $6.92 \pm 0.78^{\mathrm{a}}$ & $0.82 \pm 0.00^{\mathrm{d}}$ & $0.49 \pm 0.01$ & $3.38 \pm 0.39^{\mathrm{a}}$ & $2.78 \pm 0.32^{\mathrm{a}}$ \\
\hline
\end{tabular}

${ }^{1)}$ Control, water $700 \mathrm{~g}$; A sample, water $670 \mathrm{~g}+$ Lactic acid bacteria cultured $30 \mathrm{~g}$; B sample, water $670 \mathrm{~g}+$ Lactic acid bacteria cultured $22.5 \mathrm{~g}+$ Cinnamon extract 7.5 g; C sample, water $670 \mathrm{~g}+$ Lactic acid bacteria cultured $15 \mathrm{~g}+$ Cinnamon extract $15 \mathrm{~g}$; D sample, water $670 \mathrm{~g}+$ Lactic acid bacteria cultured $7.5 \mathrm{~g}+$ Cinnamon extract $22.5 \mathrm{~g}$; E sample, water $670 \mathrm{~g}+$ Cinnamon extract $30 \mathrm{~mL}$.

${ }^{2)}$ All values are mean $\pm S D$. Mean $\pm S D$ in column by different superscripts are significantly different at the $\mathrm{p}<0.05$ by Duncan's multiple range test.

\section{요 약}

본 연구의 목적은 유산균 배양액과 계피 추출물을 물 대신 첨가하여 제조한 sourdough의 제빵 특성과 식품첨가 물로서의 계피의 다양성을 연구하였다. 반죽의 무게는 시 료간에 차이가 없었고, 식빵의 무게는 $\mathrm{D}$ 식빵에서 가장 높았다. 식빵의 부피와 비용적은 $\mathrm{C}$ 시료에서 가장 높았고, 굽기손실율은 대조구에서 가장 높았으며 각각의 식빵 시료 간에 통계적으로 유의미한 차이가 있었다. 수분함량과 $\mathrm{pH}$ 는 계피추출물 첨가량이 증가할수록 낮아졌고, 각각의 식 빵 시료간에 통계적으로 유의미한 차이가 있었다. 적정산 도는 유산균 배양액 첨가량이 증가할수록 낮아지는 것으로 나타났으나 각각의 식빵 시료간에 통계적으로 유의미한 차이는 없었다. 색도에서 백색도는 계피첨가량이 증가할수 록 낮아졌고, 적색도와 황색도는 유산균 배양액 첨가량이 감소할수록 높아지는 것으로 나타났으며 각각의 식빵 시료 간에 통계적으로 유의미한 차이가 있었다. 식빵의 물성을 측정한 결과에서 유산균 배양액이 감소하고 계피추출물이 증가할수록 경도, 점착성 및 씹힘성은 증가하였고, 탄력성 
과 응집성은 감소하였다. $\mathrm{ALH}($ Lactobacillus sakei subsp. ALI033) 유산균 배양액과 계피 추출물을 첨가한 sourdough 로 제조한 식빵은 대조구보다 부피와 물성을 향상시키는 것으로 나타났고, 계피 추출물과 같은 부재료를 첨가하여 도 식빵 제조가 가능한 것으로 나타나 ALH 유산균 배양액 과 계피주정 추출물의 다양한 활용이 가능할 것으로 생각된 다.

\section{감사의 글}

본 연구는 농림축산식품부 고부가가치식품기술개발사 업의 연구비 지원(111143-2)으로 수행된 결과의 일부로 이 에 감사드립니다.

\section{References}

1. Kim WM, Lee YS (2004) A study on the utilization state and the choice factors of the functional bakery products. Culi Sci Hos Res, 10, 1-15

2. Woo IS, Lee JH (2015) The effect of selected properties bakery act in accordance with the customer's use of propensity to consume: Focused on Busan. Korean J Culi Res, 21, 243-253

3. Rocha JM, Malcata FX (2012) Microbiological profile of maize and rye flours, and sourdough used for the manufacture of traditional Portuguese bread. Food Microbiol, 31, 72-88

4. Choi JH, Kim E, Lee KS (2016) Quality characteristics of sourdough bread made with Kamut sour stater. Culi Sci Hos Res, 22, 117-133

5. Chang KH, Byun GI, Park SH, Kang WW (2008) Dough properties and bread qualities of wheat flour supplemented with rice bran. Korean J Food Preserv, 15, 209-213

6. Lee JR, Um YH (2004) A study of attitude toward healthy menu. Korean J Culi Res, 10, 16-29

7. Arendt EK, Ryan LAM, Dal Bello F (2007) Impact of sourdough on the texture of bread. Food Microbiol, 24, 165-174

8. Decock P, Cappelle S (2005) Bread technology and sourdough technology. Trends Food Sci Technol, 16, $113-120$

9. Gobbetti M, Rizzello CG, Di Cagno R, De Angelis M (2014) How the sourdough may affect the functional features of leavened baked goods. Food Microbiol, 37,
$30-40$

10. Katina K, Arendt E, Liukkonen KH, Autio K, Flander L, Poutanen K (2005) Potential of sourdough for healthier cereal products. Trends Food Sci Technol, 16, 104-112

11. Chiavaro E, Vittadini E, Musci M, Bianchi F, Curti E (2008) Shelf-life stability of artisanally and industrially produced durum wheat sourdough bread ("Altamura bread"). LWT Food Sci Technol, 41, 58-70

12. Hansen A, Schieberle P (2005) Generation of aroma compounds during sourdough fermentation: Applied and fundamental aspects. Trends Food Sci Technol, 16, 85-94

13. Thiele C, Ganzle MG, Vogel RF (2002) Contribution of sourdough lactobacilli, yeasts, and cereal enzymes to the generation of amino acids in dough relevant for bread flavor. Cereal Chem, 79, 45-51

14. Coda R, Cagno RD, Gobbetti M, Rizzello CG (2014) Sourdough lactic acid bacteria: Exploration of non-wheat cereal-based fermentation. Food Microbiol, 37, 51-58

15. Leroy F, De Vuyst L (2004) Lactic acid bacteria as functional starter cultures for the food fermentation industry. Trends Food Sci Technol, 15, 67-78

16. Jung KT, Park BG, Lee MH (2017) Quality characteristics of sourdough bread using fermented fig. Culi Sci Hos Res, 23, 56-65

17. Park BS (2008) Effect of dietary cinnamon powder on savor and quality of chicken meat in broiler chickens. J Korean Soc Food Sci Nutr, 37, 618-624

18. Kang HK, Choi HC, Kang BS, Na JC, Yu DJ, Kang GH, Bang HT, Park SB, Kim MJ, Seo OS, Kim DW, Kim SH (2009) Effects of dietary fermented apple pomace and cinnamon addition on meat quality and performance in broiler. J Anim Sci Technol, 51, 315-320

19. Jeong ET, Park MY, Lee JG, Chang DS (1998) Antimicrobial activity and antimutagenesis of cinnamon (Cinnamomum cassia Blume) bark extract. J Fd Hyg Safety, 13, 337-343

20. Chung HR, Lee JY, Kim DC, Hwang WI (1999) Synergistic effect of Panx ginseng and Cinnamoum Blume mixture on the inhibition of cancer cell growth in vitro. J Geinseng Res, 23, 99-104

21. Campbell AM, Penfield MP, Griswold RM (1979) The experimental study of food Houngton Miffine. Boston, MA, USA, p 459

22. AOAC (1995) Officail methods of analysis of AOAC Intl. $16^{\text {th }}$ ed, Association of official analytical Chemists, Arlinton, VA, USA, Method 943.02

23. An HL, Lee KS (2012) Effects of adding sourdough stater 
powder using Korean wheat flour on the quality of pan bread. Korean J Culi Res, 18, 183-198

24. Kim YA (2005) Effects of Lycium chinense powders on the quality characteristics of yellow layer cake. J Korean Soc Food Sci Nutr, 34, 403-407

25. Kim SK, Cheigh HS, Kwon TW, D'Appolonia BL, Marston PE (1978) Rheological and baking studies of composite flour from wheat and naked barley. Korean J Food Sci Technol, 10, 11-15

26. Choi SH, Lee SJ (2014) Quality characteristics of Korean wheat bread prepared with substitutions of naturally fermented rice starters. Korean J Culi Res, 20, 100-119

27. Hwang GH, Yun HR, Jung HN, Choi OJ (2014) Quality characteristics of baquette using fermented rice bran sourdough. Korean J Food Cook Sci, 30, 307-316
28. Lee JY, Lee SK, Cho NJ, Park WJ (2003) Development of the formula for natural bread-making starter. J Korean Soc Food Sci Nutr, 32, 1245-1252

29. Park BH, Cho HS, Park SY (2005) A study on the antioxidative effect and quality characteristics of cookies made with Lycii fructus powder. Korean J Food Cook Sci, 21, 94-102

30. Lee S, Lee JH (2013) Quality of sponge cakes supplemented with Cinnamon. J Korean Soc Food Sci Nutr, 42, 650-654

31. Song JH, Lim JA, Lee JH (2014) Quality and antioxidant properties of cookies supplemented with cinnamon powder. J Korean Soc Food Sci Nutr, 43, 1457-1461 